https://doi.org/10.15407/ukrbotj77.05.386

\title{
Gluconeogenic fructose-1,6-bisphosphatase from the mature sporocarps of common aquatic ferns: partial purification and basic characterization of this enzyme from Marsilea minuta (Polypodiopsida)
}

\author{
Shankha Shubhra GHOSH ${ }^{1}$, Madhushri DAS ${ }^{2}$, Sautrik BASU ${ }^{1 *}$, Jukta ADHIKARI ${ }^{1}$ \\ ${ }^{1}$ Post Graduate Department of Botany, Barasat Government College \\ Barasat 700124, West Bengal, India \\ ${ }^{2}$ Department of Botany, Hiralal Mazumdar Memorial College for Women \\ Dakshineswar, Kolkata 700 035, West Bengal, India \\ *basusautrik@yahoo.co.in
}

Ghosh S.S., Das M., Basu S., Adhikari J. 2020. Gluconeogenic fructose-1,6-bisphosphatase from the mature sporocarps of common aquatic ferns: partial purification and basic characterization of this enzyme from Marsilea minuta (Polypodiopsida). Ukrainian Botanical Journal, 77(5): 386-397.

Abstract. The present communication reports substantial activity of gluconeogenic fructose-1,6-bisphosphatase (FBPase; EC 3.1.3.11) in three common heterosporous aquatic ferns (Marsilea minuta, Salvinia natans, and Azolla pinnata) and also describes a protocol for its partial purification from mature sporocarps of Marsilea minuta. The cytosolic FBPase, obtained from Marsilea minuta, Salvinia natans, and Azolla pinnata was recognized as gluconeogenic enzyme due to its drastic catabolic inactivation in presence of externally administered glucose and its insensitivity towards photosynthetic light illumination. Cytosolic gluconeogenic FBPase was partially purified from mature sporocarps of Marsilea minuta to about 22-fold over homogenate following low-speed centrifugation $(11,400 \times \mathrm{g}), 30-80 \%$ ammonium sulfate fractionation followed by subsequent chromatography using matrices like CM-Cellulose, Sephadex G-200, and Ultrogel AcA 34. The profile of partially purified FBPase in PAGE under non-denaturing condition was recorded. The enzyme activity increased linearly with respect to protein concentration to about $100 \mu \mathrm{g}$ and with respect to time up to 75 minutes. Temperature optimum was found at $35^{\circ} \mathrm{C}$. The effect of substrate concentration and kinetic analyses for FBPase were carried out using D-fructose-1,6-bisphosphate (D-FBP, the substrate) in the range of 0.0 to $1.0 \mathrm{mM}$ at an interval of $0.1 \mathrm{mM}$ concentration. The $K_{m}$ value for D-FBP of FBPase was $0.06129 \mathrm{mM}$ and $V_{\max }$ was $4525 \mathrm{nmole} \mathrm{P}_{\mathrm{i}}$ released (mg) $)^{-1}$ protein $\mathrm{h}^{-1}$ as determined by nonlinear regression kinetics using Prism 8 software (Graph Pad). The enzyme was functional in a constricted $\mathrm{pH}$ range of 7.0 to 8.0 , giving maxima at $\mathrm{pH}$ 7.5. This cytosolic enzyme was significantly stimulated by $\mathrm{Mg}^{2+}$ and strongly inhibited by $\mathrm{Hg}^{2+}, \mathrm{Cu}^{2+}$ and $\mathrm{Zn}^{2+}$.

Keywords: aquatic fern, enzyme purification and characterization, FBPase, gluconeogenesis, sporocarp

Submitted 01 June 2020. Published 31 October 2020

(C) 2020 S.S. Ghosh, M. Das, S. Basu, J. Adhikari. Published by the M.G. Kholodny Institute of Botany, NAS of Ukraine. This is an open access article under the terms of the Creative Commons Attribution License (http://creativecommons.org/licenses/by/4.0/), which permits use, distribution, and reproduction in any medium, provided the original work is properly cited 
Гош С.С. ${ }^{1}$, Дас M. ${ }^{2}$, Басу С. ${ }^{1}$, Адікарі Ю. ${ }^{1}$ 2020. Глюконеогенна фруктозо-1,6-бісфосфатаза зрілих спорокарпів звичайних видів водяних папоротей: часткове очищення та основна характеристика цього ферменту у Marsilea minuta (Polypodiopsida). Украӥнський ботанічний журнал, 77(5): 386-397.

${ }^{1}$ Кафедра ботаніки, Державний коледж м. Барасат

Барасат 700124, Західна Бенгалія, Індія

${ }^{2}$ Кафедра ботаніки, Меморіальний жіночий коледж Хіралал Мазумдар

Дакшинесвар, Колката 700 035, Західна Бенгалія, Індія

Реферат. У статті повідомляється про значну активність глюконеогенної фруктозо-1,6-бісфосфатази (ФБФ-аза; КФ 3.1.3.11) у трьох звичайних видів гетероспорових водяних папоротей (Marsilea minuta, Salvinia natans i Azolla pinnata). Крім того, наводиться протокол часткового очищення цього ферменту із зрілих спорокарпів Marsilea minuta. Цитозольна ФБФ-аза, отримана з Marsilea minuta, Salvinia natans та Azolla pinnata, визнана глюконеогенним ферментом завдяки різкій катаболічній інактивації за наявності зовнішньо введеної глюкози та нечутливості до фотосинтетичного освітлення. Цитозольна глюконеогенна ФБФ-аза із зрілих спорокарпів Marsilea minuta була частково очищена до приблизно 22-кратного рівня гомогенатом після низькошвидкісного центрифугування $(11400 \times \mathrm{g})$, фракціонування 30-80\% сульфатом амонію і подальшого хроматографічного розділення на СМ-целюлозі, Sephadex G-200 та Ultrogel АсА 34. Реєстрували профіль частково очищеної ФБФ-ази шляхом електрофорезу у нативних умовах в поліакриламідному гелі (РАGE). Активність ферменту лінійно зростала щодо концентрації білка приблизно до 100 мг упродовж періоду до 75 хвилин. Температурний оптимум установлено при $35^{\circ} \mathrm{C}$. Для визначення впливу концентрації субстрату і кінетичного аналізу використовували D-фруктозо-1,6-бісфосфат (D-ФБФ, субстрат) у діапазоні 0,0-1,0 mM з інтервалом 0,1 mМ концентрації. Значення $K_{m}$ для D-ФБФ ФБФ-ази становило $0,06129 \mathrm{mM}$, a $V_{\max }-4525 \mathrm{nmole}_{\mathrm{i}}$ виділеного білка $\mathrm{h}^{-1}(\mathrm{mg})^{-1}$, що визначали за допомогою нелінійної регресії з використанням програм Prism 8 (Graph Pad). Дія ферменту відбувалась у звуженому діапазоні рН від 7-8, а максимальні показники отримано при $\mathrm{pH} 7,5$. Встановлено, що $\mathrm{Mg}^{2+}$ значною мірою стимулює, а $\mathrm{Hg}^{2+}, \mathrm{Cu}^{2+} \mathrm{i} \mathrm{Zn}^{2+}-$ інгібують активність цього цитозольного ферменту.

Ключові слова: водяна папороть, глюконеогенез, очищення та характеристика ферментів, ФБФ-аза, спорокарп

\section{List of abbreviations}

BSA - bovine serum albumin; CM - carboxymethyl; EDTA - ethylene diaminetetraacetate; F-6-P - fructose6-phosphate; FBP - fructose-1,6-bisphosphate; FBPase fructose-1,6-bisphosphatase; g - gravitational field; $K_{m}$ - michaelis constant; OD - optical density; PAGE polyacylamide gel electrophoresis; $\mathrm{P}_{\mathrm{i}}-$ inorganic phosphate; $V_{\max }$ - maximum velocity.

\section{Introduction}

Aquatic ferns bear specialized and unique reproductive structures known as 'sporocarps'. These are sclerified seed-like propagules whose morphological nature has been variously interpreted. It is now generally agreed that these specialized, stomatiferous foliar units are modified leaflets with two reflexed and connate segments, each bearing a number of elongate sori following the veins (Kramer, 1990). The young immature sporocarps are green, leathery and photosynthetic, while on maturation they become non-photosynthetic, blackish brown in colour and eventually break down as a result of disintegration of the indusial and the sporangial walls releasing the spores to the external environment. These unique desiccation tolerant structures have been extensively studied from various angles like morphology, anatomy, physiology, cytology, phytoremediation, environmental biology, phylogeny, antioxidant activity, etc. over a period of several decades (Bierhorst, 1971; Bold et al., 1987; Gifford, Foster, 1987; Raubeson et al., 1994; Rothwell, Stockey, 1994; Nagalingum et al., 2006; Sood et al., 2012; Arokiyaraj et al., 2018). However, a thorough biochemical analysis of this specialized structure during its development has not been conducted adequately. There is a dearth of information regarding the biochemical aspects of sporocarp maturation and sprouting. It has been reported earlier that adequate glucose concentration is the central parameter in living organisms for optimization and fulfilment of all metabolic events either directly or indirectly (Eckstein et al., 2012). In plants this sugar is available in all parts basically via photosynthesis in leaves followed by phloem translocation. It has also been observed that under certain physiological conditions, the requisite concentration of glucose is provided via non-photosynthetic pathway like gluconeogenesis. The conversion of immature fern sporocarps into mature and senescent ones involves a definite loss of photosynthetic activity which in turn indicates the possible occurrence of gluconeogenic pathway and the concomitant involvement of the gluconeogenic marker enzyme, fructose-1,6bisphosphatase (FBPase).

Fructose-1,6-bisphosphatase is a ubiquitous enzyme which catalyzes the hydrolytic dephosphorylation of D-fructose-1,6-bisphosphate (Fru-1,6- $\mathrm{P}_{2}$ ) to D-fructose- 
6-phosphate and inorganic phosphate. Two isoforms of FBPase has been recognized for more than five decades. The first one is associated with the photosynthetic plastids and is involved in the reductive carbon assimilation cycle of photosynthesis. The second is located in the cytoplasm, which is involved in both gluconeogenesis and sucrose synthesis (Zimmerman et al., 1978; Stitt, Heldt, 1985). Cytosolic fructose-1,6-bisphosphatase is primarily associated with the regulation of gluconeogenesis in non-photosynthetic tissues like mature fern sporocarps. The occurrence of gluconeogenic FBPase is widespread in living organisms vacillating from bacteria to highly structured plants and animals. Several workers have studied this ancestral gluconeogenic enzyme from a wide number of microbial, plant and animal genera with diverse phylogenetic significance (Kobr, Beevers, 1971; Yu, 1989; Botha, Turpin, 1990; Jardon et al., 2008; Dey et al., 2014). However, perusal of available literature clearly reveals a serious information gap regarding the existence of this enzyme in vascular cryptogams, particularly in non-green senescent sporocarps of common aquatic ferns like Marsilea sp., Salvinia sp., and Azolla sp. Taking all the above facts into consideration the present investigation was aimed towards detection, partial purification and characterization of this ancestral gluconeogenic enzyme from three common heterosporous water ferns belonging to Marsileaceae and Salviniaceae.

\section{Materials and methods}

\section{Chemicals and reagents}

D-fructose-1,6-bisphosphate(di-sodium salt), D-fructose6-phosphate (di-sodium salt), D-glucose-6-phosphate (di-sodium salt), D-galactose-6-phosphate (Gal-6-P, disodium salt), D-fructose-6-phosphate (F-6-P, di-sodium salt), D-mannose-6-phosphate (M-6-P, di-sodium salt), bovine serum albumin (BSA), were obtained from SRL (Mumbai, India). 2-Mercaptoethanol (ME), ammonium molybdate, acetic acid, ammonium sulphate, ammonium chloride, copper chloride, potassium chloride, tris(hydroxymethyl)aminomethane, trichloroacetic acid (TCA), dipotassium hydrogen phosphate, magnesium chloride, hydrochloric acid, sodium chloride, sulphuric acid, zinc chloride were purchased from E Merck India Ltd. (Mumbai, India). 2-Glycerophosphate was obtained from BDH, England. Coomassie Brilliant Blue (R-250 and G-250), Ultrogel AcA 34 (U8878) were obtained from Sigma Chemical Company, St. Louis, Missouri,
USA. Sephadex G-200 was obtained from Amersham Pharmacia Biotech marketed by SRL, Mumbai, India. Ascorbic acid, sodium bicarbonate, ammonium sulfate and ammonium chloride were procured from SRL (Mumbai, India). CM-Cellulose column matrix was purchased from Genei, Bangalore, India. Manganese chloride, dialysis membrane, etc. were obtained from Hi Media Laboratories Ltd. (Mumbai, India). Mercuric chloride and calcium chloride were obtained from Qualigens Fine Chemicals (Mumbai, India). All other chemicals used were of analytical grade and acquired from renowned Indian companies.

\section{Plant material}

Sporocarps of Marsilea minuta L., Salvinia natans L., and Azolla pinnata R.Br. were collected in different seasons from different ponds and paddy fields of Bongaon $\left(23^{\circ} 4^{\prime} \mathrm{N}, 88^{\circ} 49^{\prime} \mathrm{E}\right)$ and Hasnabad $\left(22.5^{\circ} 7^{\prime} \mathrm{N}\right.$, $88.9^{\circ} 1^{\prime}$ E), 24-Parganas $(\mathrm{N})$, WB, India in fresh condition and kept under $-20{ }^{\circ} \mathrm{C}$ in the laboratory until use. Specimens were identified using standard taxonomic literature and herbarium specimens available at Central National Herbarium (CAL). Voucher specimens were deposited in the Departmental herbarium of Barasat Govt. College.

\section{Isolation of fructose-1,6-bisphosphatase}

In order to assay the enzyme (FBPase), and for detecting its activity in the sporocarps of the experimental samples separately at the initial phase of our work, the enzyme was isolated according to the following steps. The experimental material (about 10 gms) were collected and washed thrice with chilled distilled water and homogenized in a pre-cooled mortar and pestle in two volumes of the extraction buffer $[50 \mathrm{mM}$ tris-acetate ( $\mathrm{pH} 7.5$ ) containing $0.2 \mathrm{mM} \beta$-mercaptoethanol (ME)]. Neutral sea-sand was used in the mortar during the process of extraction. This homogenate was filtered to eliminate sand, unbroken cells and cellular debris. The resultant residue was discarded and the filtrate (homogenate) was collected. Half of the total volume of the filtrate was centrifuged at $11,400 \times \mathrm{g}$ for 30 minutes in a Remi $\mathrm{C}$ 24 Plus cold centrifuge and the pellet was discarded. The supernatant (low-speed supernatant fraction) thus obtained was dialyzed overnight against the same buffer solution used for homogenization. On completion of dialysis, the low-speed supernatant was recovered from the dialysis bag and used for the preliminary assay. 


\section{Assay of fructose-1,6-bisphosphatase}

A simple assay method of fructose-1,6-bisphosphatase was designed during the course of the present investigation in our laboratory, based on the method of Biswas et al. (1981). The typical incubation mixture restricted $100 \mathrm{mM}$ tris-acetate buffer $(\mathrm{pH} 7.5), 5 \mathrm{mM}$ $\mathrm{MgCl}_{2}, 0.2 \mathrm{mM}$ fructose-1,6-bisphosphate (FBP), 0.1 $\mathrm{mM}$ EDTA, and an appropriate protein aliquot (50-200 $\mu \mathrm{g}$ ) in a total volume of $1.0 \mathrm{~mL} .0 .2 \mathrm{mM}$ fructose6-phosphate (F-6-P) substituted FBP in each set of assay which served as control against non-specific phosphatases. Zero minute controls for both FBP and F-6-P, where the protein of the incubation mixture was destroyed by $0.25 \mathrm{~mL}$ of $20 \%$ chilled trichloroacetic acid (TCA) prior to the addition of substrate, served as double check against prying inorganic phosphate (if any). In totalling to these sets, an appropriate blank (minus enzyme) was also maintained. The enzyme incubation was carried out at $37^{\circ} \mathrm{C}$ for 1 hour. After 1 hour of first (enzyme) incubation, the reaction was finished by the procedure applied for zero minute control. Therefore, in an assay set, there were six tubes, i.e., one blank, one zero minute control and one experimental tubes for each set (i.e., FBP set and F-6-P set). Afterwards, the amount of inorganic phosphate released on hydrolysis from the substrate(s) by the enzyme action was estimated according to the procedure of Chen et al. (1956) with slight modifications (Adhikari et al., 1987). $3.0 \mathrm{~mL}$ of a reagent ( $\mathrm{P}_{\mathrm{i}}$-reagent) and $3.0 \mathrm{~mL} \mathrm{H}_{2} \mathrm{O}$ were added to the reaction mixture (total volume thus became $7.25 \mathrm{~mL}$ ) and incubated at $37{ }^{\circ} \mathrm{C}$ for 1 hour. The $\mathrm{P}_{\mathrm{i}}$-reagent was prepared immediately before use by adding $\mathrm{H}_{2} \mathrm{SO}_{4}(6 \mathrm{~N})$, ascorbic acid $(10 \% \mathrm{w} / \mathrm{v})$, ice-cold ammonium molybdate $(2.5 \% \mathrm{w} / \mathrm{v})$ and $\mathrm{H}_{2} \mathrm{O}$ in 1:1:1:2 ratios in that order. After incubation, the blue colour developed was measured at $820 \mathrm{~nm}$ in a Systronics-106 spectrophotometer. The free inorganic phosphate was estimated with the help of a standard curve prepared from different known quantities $(0-100 \mu \mathrm{g})$ of phosphorous $\left(\mathrm{K}_{2} \mathrm{HPO}_{4}\right.$ was used as the source). The enzyme-dependent release of inorganic phosphate was considered by subtracting the second corrected value (experimental tube - zero minute tube of 'FBP set') from the first corrected value (experimental tube - zero minute tube of 'F-6-P set'). Protein was estimated by the method of Bradford (1976) with minor modifications using BSA as standard. A standard curve could thus be obtained and using that, the protein content of the experimental samples were estimated. As 1 mole of inorganic phosphate was hydrolyzed from one mole of
FBP, mole number of inorganic phosphate quantified was equal to the number of FBP hydrolyzed at $\mathrm{C}-1$ position.

Catabolic inactivation by externally administered glucose

In set I, sporocarps of Marsilea minuta, Salvinia natans, and Azolla pinnata were washed with distilled water and then two similar batches were designed, each containing 2 gms of fresh tissue for each individual genus. These experimental materials belonging to each batch were than kept in two different petri plates over moist filter paper (soaked thoroughly with distilled water). The experimental sets were maintained in presence of $5 \%$ glucose (at 24 $26{ }^{\circ} \mathrm{C}$ ) and control sets were also maintained parallel without glucose under similar temperature regimes. This treatment was carried out for 7 days and rotational light / dark condition was maintained identically for both the sets (experimental \& control). After completion of the treatment, respective homogenate (s) of the tissues were prepared independently from both the sets (materials placed separately in presence of $0 \%$ and $5 \%$ glucose). FBPase assay was carried out following the procedure described in the previous section.

\section{Influence under photosynthetic light}

In set II, Marsilea minuta, Salvinia natans, and Azolla pinnata were washed with distilled water and then two similar batches were designed, each containing 2 gms of fresh tissue. These materials of each batch and for each genera were then maintained in two different petri plates over moist filter paper (soaked thoroughly with distilled water). One of these investigational sets were placed under alternate light/dark condition (8 hours light, 16 hours dark) for 7 days and the control set was maintained under complete darkness for 7 days. Subsequent to 7 days of treatment, respective homogenate (s) of the tissues were prepared independently from both the batches. FBPase assay was carried out following the procedure described earlier.

\section{Partial purification of FBPase (from the sporocarps of Marsilea minuta)}

10 gms of mature Marsilea sporocarps were washed with chilled distilled water twice and the partial purification of the cytosolic fructose-1,6-bisphosphatase from this sample was carried out following the steps as mentioned below (all the steps were carried out under 0 to $\left.4{ }^{\circ} \mathrm{C}\right)$. 


\section{Homogenate}

Water-washed sporocarps of Marsilea minuta was homogenized in a mortar and pestle with 2-volumes of $50 \mathrm{mM}$ tris-acetate (pH 7.5) buffer containing $0.2 \mathrm{mM}$ $\mathrm{ME}$ in presence of a little amount of washed sand. This homogenate was filtered to eliminate the sand, unbroken cells and cellular debris. The resultant residue was discarded and the filtrate (homogenate) collected.

\section{Low speed supernatant}

The resultant homogenate was centrifuged at $11,400 \times \mathrm{g}$ for 30 minutes in a Remi C-24 Plus cold centrifuge. On completion of centrifugation, the pellet was discarded and the supernatant fraction was collected from the centrifuge tubes and pooled together.

\section{Ammonium sulphate fractionation}

The low-speed supernatant fraction obtained from the preceding step was then made $30-80 \%$ saturated with $\left(\mathrm{NH}_{4}\right)_{2} \mathrm{SO}_{4}$ by adding requisite amount of solid salt slowly with constant rousing (by using a Remi magneticstirrer). Then it was kept at $0{ }^{\circ} \mathrm{C}$ for 30 minutes and then centrifuged at $11,400 \times \mathrm{g}$ for 30 minutes using Remi C-24 Plus cold centrifuge. The resultant pellet thus obtained after this centrifugation was dissolved in minimal volume of $50 \mathrm{mM}$ tris-acetate ( $\mathrm{pH} 7.5$ ) buffer having $0.2 \mathrm{mM} \mathrm{ME}$ and dialyzed overnight against the same buffer (at least 1000 volumes) for complete removal of $\left(\mathrm{NH}_{4}\right)_{2} \mathrm{SO}_{4}$. On completion of dialysis, the $30-80 \%\left(\mathrm{NH}_{4}\right)_{2} \mathrm{SO}_{4}$ fraction was recovered from the dialysis bag.

\section{Cation exchange column chromatography through CM-cellulose}

The $30-80 \%$ ammonium sulphate (dialyzed) fraction obtained from the earlier step were loaded onto a column $(0.8 \times 10.9 \mathrm{~cm})$ of $\mathrm{CM}$-cellulose [before this experimentation, commercially available CM-cellulose was flooded with 300-400 volumes of glass-distilled water over-night at room-temperature for complete swelling of gel beads. The excess water was then poured out and the column material equilibrated earlier with $50 \mathrm{mM}$ tris-acetate buffer ( $\mathrm{pH}$ 7.5) having 0.2 mM ME] pre-equlibrated with $50 \mathrm{Mm}$ tris-acetate buffer $(\mathrm{pH} 7.5)$ containing $0.2 \mathrm{mM} \mathrm{ME}$. Proteins were eluted with the same buffer with $\mathrm{KCl}$ gradient $(0.0$ to $0.5 \mathrm{M})$ in fractions of $4.0 \mathrm{~mL}$ at a flow rate of 20 minutes per tube. Fifteen such fractions were collected. Fractions containing fructose1,6-bisphosphatase activities were pooled collectively and this preparation was stored at $-20^{\circ} \mathrm{C}$.

\section{Gel filtration through Sephadex G-200}

Active CM-cellulose fractions were pooled together and column chromatography was carried out through Sephadex G-200 $(0.8 \times 14.0 \mathrm{~cm})$. Proteins were eluted with the $50 \mathrm{mM}$ tris-acetate buffer $(\mathrm{pH} \mathrm{7.5)}$ having $0.2 \mathrm{mM} \mathrm{ME}$ in fractions of $3.0 \mathrm{~mL}$ at a flow rate of 25 minutes per tube. Eighteen such fractions were collected. The FBPase active Sephadex G-200 fractions were pooled together and molecular sieve chromatogram was made through UltrogelAcA 34 column.

\section{Molecular sieve chromatography through UltrogelAcA 34}

Active Sephadex G-200 fractions were pooled together and column chromatography was carried out through UltrogelAcA 34 column $(0.8 \times 9.5 \mathrm{~cm})$. Proteins were eluted with the same buffer in fractions of $2.5 \mathrm{~mL}$ at a flow rate of 15 minutes per tube. Fifteen such fractions were collected. The FBPase active fractions obtained from UltrogelAcA 34 were pooled together and used as the enzyme preparation for biochemical characterization of FBPase.

\section{Characterization of FBPase}

Polyacrylamide gel electrophoresis was performed under native conditions following the method of Bollag et al. (1996) with minor modifications. All other experiments were carried out following conventional methods of enzymology.

\section{Kinetic analysis}

The $K_{m}$ value for D-FBP of FBPase was $0.2215 \mathrm{mM}$ and $V_{\max }$ was 7663 nmole $\mathrm{P}_{\mathrm{i}}$ released $(\mathrm{mg})^{-1}$ protein $\mathrm{h}^{-1}$ as determined by nonlinear regression kinetics using Prism 8 software (Graph Pad). All experiments were repeated thrice and results were expressed as means $\pm \mathrm{SE}$ of three replicates.

\section{Results}

\section{Screening of FBPase}

Both young (green) and mature (brownish black) sporocarps of Marsilea minuta, Salvinia natans, and Azolla pinnata were screened separately for the presence of FBPase. In the young sporocarps of all the experimental samples, the specific activity of FBPase was relatively lower than the mature sporocarps obtained from the same source (Table 1). 

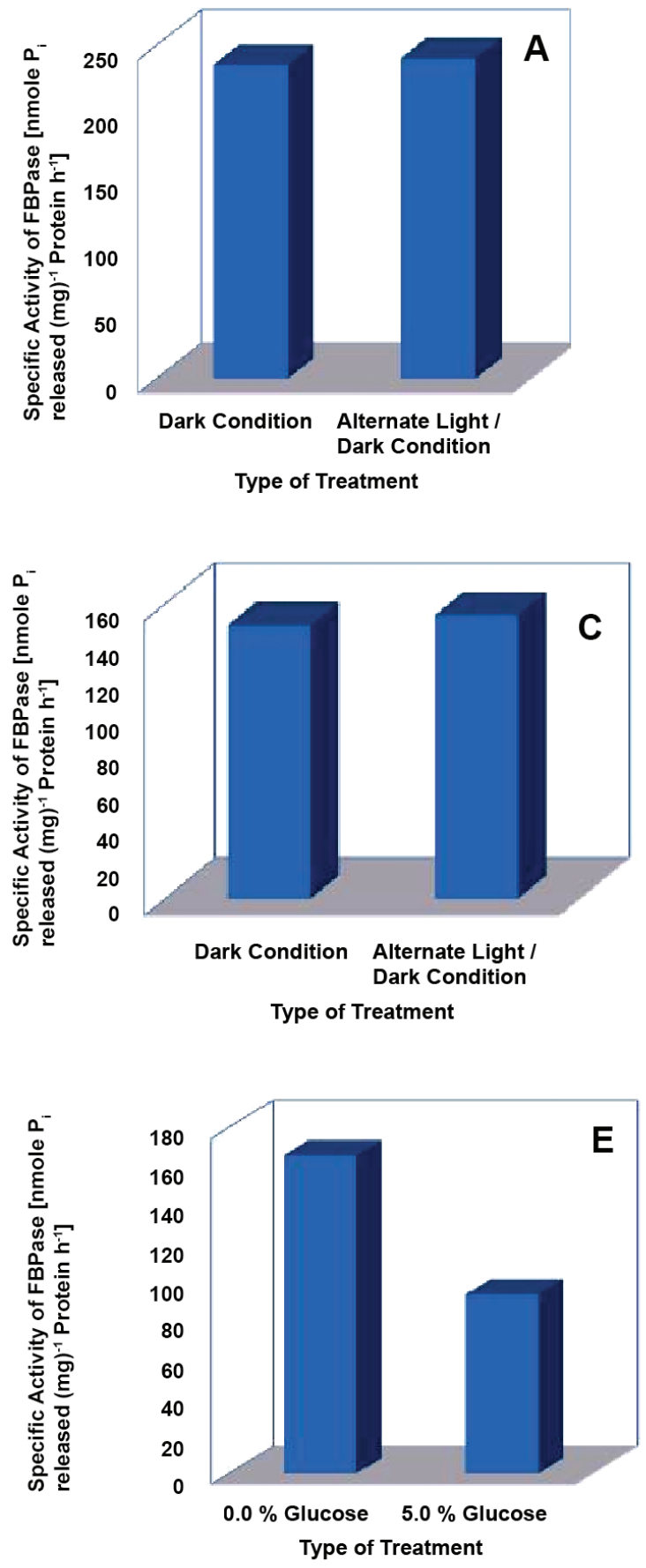
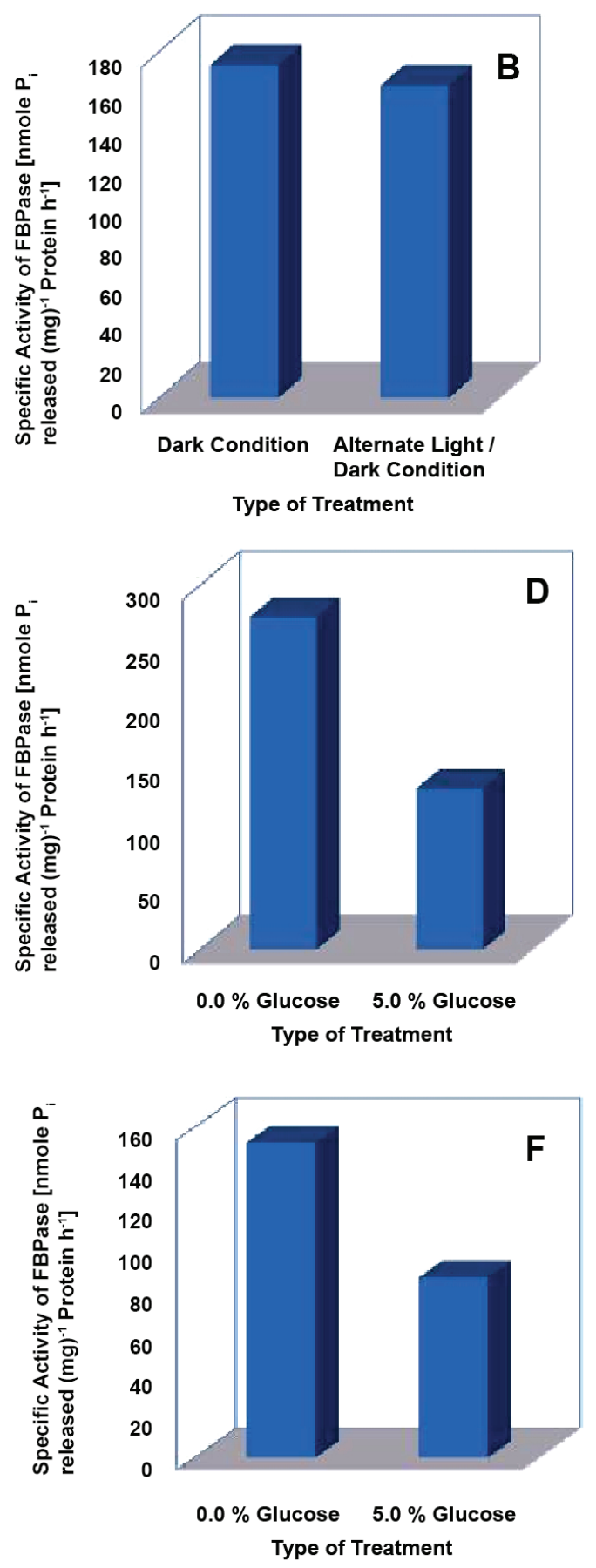

Fig. 1. A-C: uninfluenced activity of FBPase under photosynthetic light illumination for 7 days in Marsilea minuta (A), Salvinia natans (B), and Azolla pinnata (C); D-F: catabolic inactivation of FBPase activity by externally administered glucose (5\%) for 7 days in Marsilea minuta (D), Salvinia natans (E), and Azolla pinnata (F) 

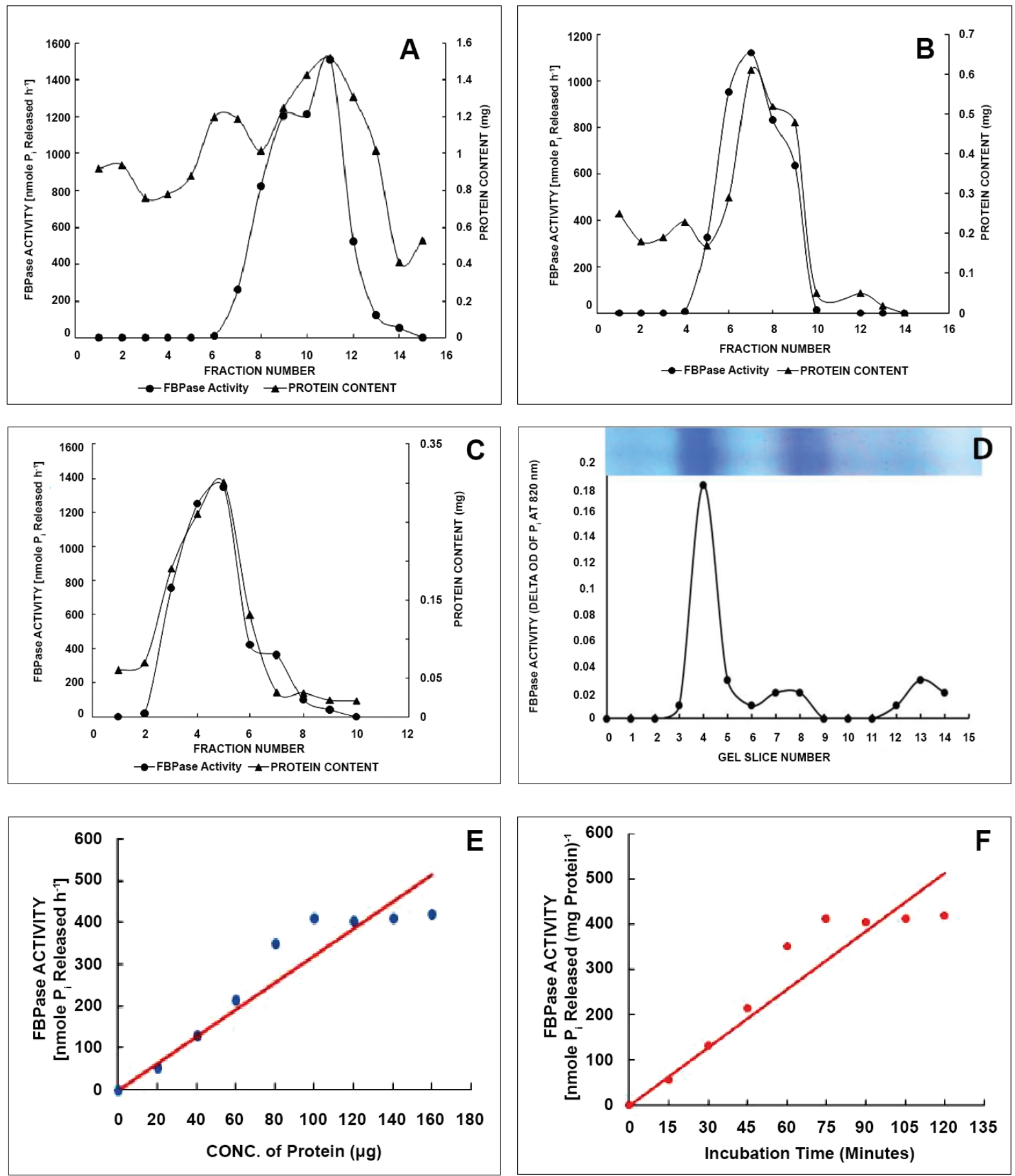

Fig. 2. A-C: elution profiles of FBPase and protein contents through CM-cellulose column (A), Sephadex G-200 column (B), and Ultrogel AcA34 column (C); D: Native PAGE profile with corresponding FBPase activity; E: effect of protein concentration on FBPase activity; F: effect of incubation time on FBPase activity 
Table 1. Activity of fructose-1,6-bisphosphtase from young and mature sporocarps of common aquatic ferns from low-speed supernatant fraction $(11,400 \times g)$ [Results are mean $\pm S E, n=3$ ]

\begin{tabular}{|c|c|c|c|}
\hline Plant & Plant part & $\begin{array}{l}\text { Growth stage of sporocarps } \\
\text { and collection period }\end{array}$ & $\begin{array}{l}\text { Specific activity of FBPase } \\
\left(\text { nmole } P_{i} \text { released }(\mathrm{mg})^{-1} \mathrm{~h}^{-1}\right.\end{array}$ \\
\hline \multirow{2}{*}{ Azolla pinnata } & \multirow{2}{*}{ Sporocarps } & Young ( June 2019) & $28.16 \pm 4.21$ \\
\hline & & Mature (September 2019) & $159.45 \pm 25.77$ \\
\hline \multirow{2}{*}{ Marsilea minuta } & \multirow{2}{*}{ Sporocarps } & Young (November 2019) & $122.36 \pm 18.05$ \\
\hline & & Mature (February 2019) & $210.16 \pm 31.44$ \\
\hline \multirow{2}{*}{ Salvinia natans } & \multirow{2}{*}{ Sporocarps } & Young (December 2019) & $71.22 \pm 8.46$ \\
\hline & & Mature (March 2019) & $176.31 \pm 22.52$ \\
\hline
\end{tabular}

\section{Identification of gluconeogenic FBPase}

The activity of such FBPase in mature sporocarps remained unaltered under alternative light/dark conditions (Fig. 1, A-C) but, it was subdued under the presence of externally administered glucose for all the investigated genera (Fig. 1, D-F).

\section{Partial purification of FBPase from the mature} sporocarps of Marsilea minuta

This enzyme was partially purified from the mature sporocarps of Marsilea minuta to about 22-fold and with about $71 \%$ yield over homogenate following low-speed centrifugation $(11,400 \times \mathrm{g}), 30-80 \%$ ammonium sulfate fractionation followed by subsequent chromatography using matrices like CM-cellulose, Sephadex G-200 and Ultrogel AcA 34 as detailed earlier in the methods section (Table 2). The general blueprint of elution profile of cytosolic FBPase and proteins are presented in Fig. 2, $\mathrm{A}-\mathrm{C}$.

\section{Characterization of FBPase}

The Partially purified FBPase profile was identified in PAGE under non-dissociating condition. Two major bands were marked in the native PAGE profile, out of which the first major protein band was found to coincide with the enzyme activity (Fig. 2, D). This partially purified enzyme exhibited variable activity in absence of different assay components (Table 3). The enzyme activity increased linearly with respect to protein concentration to about $100 \mu \mathrm{g}$ (Fig. 2, E) and with respect to time up to $75 \mathrm{~min}$ (Fig. 2, F). Temperature optimum was found at $35{ }^{\circ} \mathrm{C}$ (Fig. 3, A). The effect of substrate concentration and kinetic analyses for FBPase were carried out using D-fructose-1,6-phosphate (D-FBP, the substrate) in the range of 0.0 to $1.0 \mathrm{mM}$ at an interval of $0.1 \mathrm{mM}$. The $K_{m}$ value for D-FBP of FBPase was 0.06129 $\mathrm{mM}$ and $V_{\max }$ was 4525 nmole $\mathrm{P}_{\mathrm{i}}$ released $(\mathrm{mg})^{-1}$ Protein $\mathrm{h}^{-1}$ as determined by nonlinear regression kinetics using Prism 8 software (Graph Pad) (Fig. 3, C). This FBPase specifically utilized fructose-1,6-bisphosphatase as its exclusive substrate. No other phosphorylated sugar could replace it (Table 4). The enzyme was functional in a confined $\mathrm{pH} 7-8$ giving maxima at $\mathrm{pH} 7.5$ using tris- $\mathrm{HCl}$ buffer in experiments (Fig. 3, B). This cytosolic enzyme was significantly stimulated by $\mathrm{Mg}^{2+}$ and highly subdued by $\mathrm{Hg}^{2+}, \mathrm{Cu}^{2+}$, and $\mathrm{Zn}^{2+}$ (Fig. 3, D).

\section{Discussion}

The reproductive structures of heterosporous ferns although referred collectively under a common term 'sporocarp', each structure is unique to their respective genera and are strikingly different from each other. The difference lies in terms of gross morphology, anatomy, time of maturation and mechanism of dispersal. Previous

Table 2. Partial purification of gluconeogenic FBPase from non-photosynthetic sporocarps of Marsilea minuta [Results are mean $\pm \mathrm{SE}, \mathrm{n}=3$ ]

\begin{tabular}{|l|c|c|c|c|c|}
\hline \multicolumn{1}{|c|}{ Fraction } & $\begin{array}{c}\text { Total } \\
\text { protein } \\
(\mathrm{mg})\end{array}$ & $\begin{array}{c}\text { Specific activity } \\
{\left[\mathrm{nmole} \mathrm{P}_{\mathrm{i}} \text { released }\right.} \\
\left.(\mathrm{mg})^{-1} \text { protein h}^{-1}\right]\end{array}$ & $\begin{array}{c}\text { Total activity } \\
{\left[\text { nmole } \mathrm{P}_{\mathrm{i}} \text { released } \mathrm{h}^{-1}\right]}\end{array}$ & $\begin{array}{c}\text { Yield } \\
(\%)\end{array}$ & $\begin{array}{c}\text { Fold purification } \\
(\text { Fold })\end{array}$ \\
\hline Homogenate fraction & $27.08 \pm 2.46$ & $176.90 \pm 16.11$ & $4790.45 \pm 6.48$ & $100.00 \pm 2.14$ & $1.00 \pm 0.03$ \\
\hline $11,400 \times \mathrm{g}$ supernatant fraction & $22.83 \pm 2.13$ & $201.32 \pm 30.34$ & $4596.13 \pm 4.11$ & $95.94 \pm 3.06$ & $1.13 \pm 0.04$ \\
\hline $30-80 \%\left(\mathrm{NH}_{4}\right)_{2} \mathrm{SO}_{4}$ fraction & $18.75 \pm 3.86$ & $237.05 \pm 26.71$ & $4444.68 \pm 12.34$ & $92.78 \pm 7.16$ & $1.34 \pm 0.11$ \\
\hline CM-cellulose fraction & $3.93 \pm 6.42$ & $1106.15 \pm 5.43$ & $4347.16 \pm 6.73$ & $90.74 \pm 5.49$ & $6.25 \pm 0.43$ \\
\hline Sephadex G-200 fraction & $2.06 \pm 5.09$ & $1706.42 \pm 2.11$ & $3515.22 \pm 1.26$ & $73.37 \pm 4.88$ & $9.64 \pm 1.31$ \\
\hline UltrogelAcA 34 fraction & $0.85 \pm 0.13$ & $4035.16 \pm 1.50$ & $3429.88 \pm 32.14$ & $71.59 \pm 2.73$ & $22.18 \pm 1.14$ \\
\hline
\end{tabular}



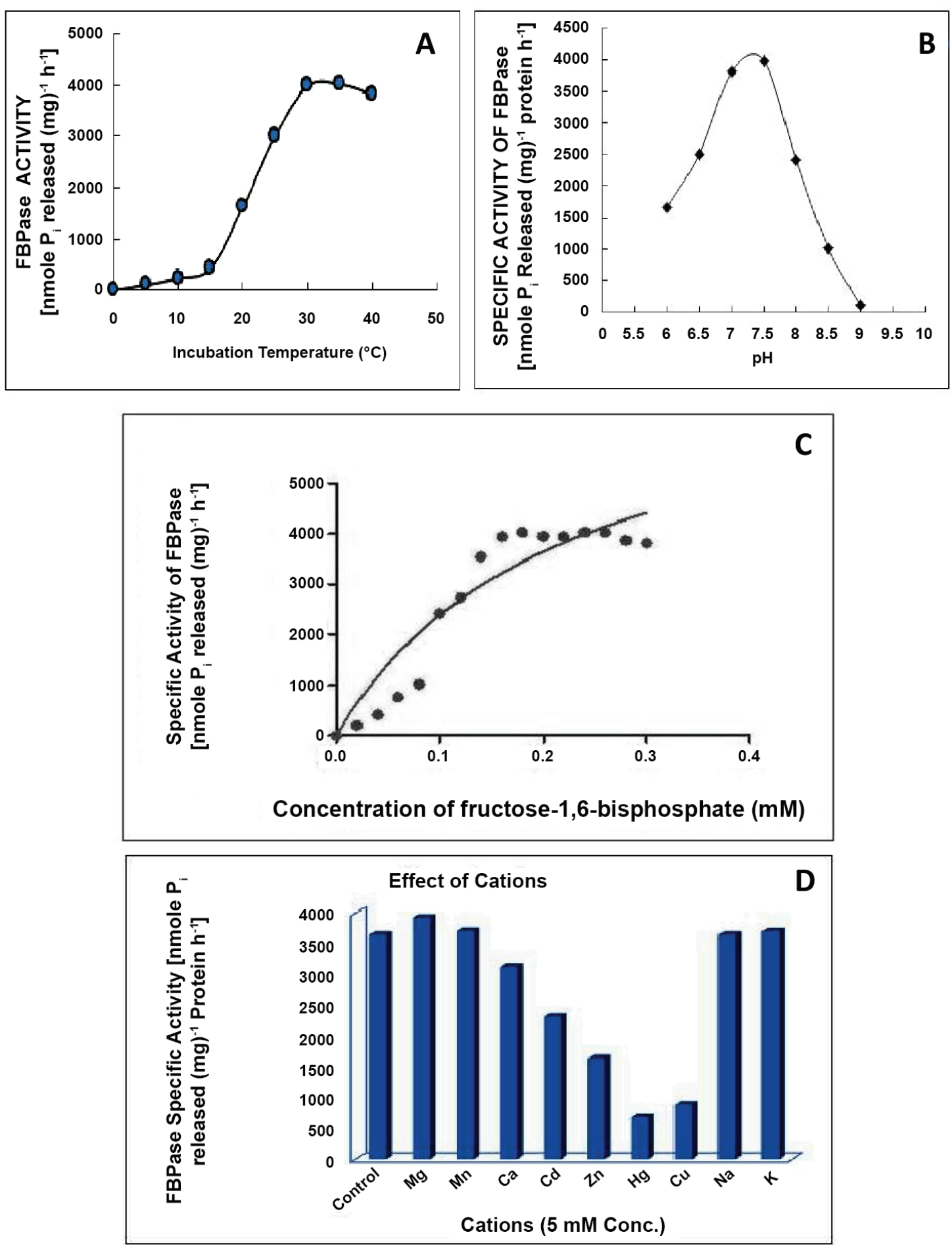

Fig. 3. A: effect of incubation temperature on FBPase activity; B: pH sensitivity of partially purified cytosolic FBPase; C: effect of substrate concentration on FBPase activity; D: effect of some monovalent and divalent cations on cytosolic FBPase activity 
Table 3. Effect of different assay components on FBPase activity [Results are mean $\pm \mathrm{SE}, \mathrm{n}=3$ ]

\begin{tabular}{|l|l|c|c|}
\hline $\begin{array}{r}\text { Sl. } \\
\text { No. }\end{array}$ & \multicolumn{1}{|c|}{ Condition } & $\begin{array}{c}\text { Specific activity } \\
{\left[\mathrm{nmole} \mathrm{P}_{\mathrm{i}} \text { released }\right.} \\
\left.(\mathrm{mg})^{-1} \text { protein }^{-1}\right]\end{array}$ & $\begin{array}{c}\text { An average } \\
\text { activity }(\%)\end{array}$ \\
\hline 1 & Complete set & $3853.46 \pm 234.11$ & 100.00 \\
\hline 2 & Minus substrate (FBP) & 0.00 & 0.00 \\
\hline 3 & Minus buffer & $3326.05 \pm 187.19$ & 86.31 \\
\hline 4 & Minus $\mathrm{MgCl}_{2}$ & $3642.85 \pm 206.15$ & 94.53 \\
\hline 5 & Minus EDTA & $3516.31 \pm 188.32$ & 91.25 \\
\hline 6 & Heat killed enzyme & 0.00 & 0.00 \\
\hline
\end{tabular}

reports are also indicative of the fact that because of the striking overall morphological differences among the spore-bearing structures, the two heterosporous fern families Marsileaceae and Salviniaceae are not considered to be related closely (Bower, 1928; Eames, 1936; Tryon, Tryon, 1982). In the present investigation the activity of cytosolic FBPase was found to vary considerably among the three aquatic ferns screened. The activity varied considerably according to the growth stage of the collected sporocarps. Young and immature sporocarps exhibited a low enzyme titre value while maximum activity was recorded in mature sporocarps which were about to dehisce. Out of the three species scanned, highest activity was recorded in mature sporocarps of Marsilea followed by Salvinia and Azolla, respectively (Table 1) and this may be due to genotypic and physiological differences and other accompanying environmental factors.

The elevated activity of this enzyme in senescent sporocarps in comparison with their juvenile counterparts (Table 1) raises a very pertinent question regarding its actual physiological significance, which is yet to be conclusively resolved. A possible explanation of this phenomenon can be given from a biochemical point of view. Fern sporocarps are unusual modified reproductive structures that are reported to be highly desiccation tolerant [some are known to be viable 40 years after being collected (Bierhorst, 1971; Johnson, 1985)]. These structures have thick, sclerenchymatous walls that provide adequate protection against dryness and mechanical damage by insect herbivores. During maturation and before dispersal the sporocarp has to cope up with internal stress from the turgor developed. Just prior to spore dispersal the shielding coat of the sporocarp breaks down due to its prolonged acquaintance with water or a scratchy surface. Hydration changes the internal components and a gelatinous frame of pectin (i.e., the sorophore) comes out from the sporocarp.
Table 4. Substrate specificity on FBPase activity [Results are mean $\pm \mathrm{SE}, \mathbf{n}=3$ ]

\begin{tabular}{|l|c|c|c|}
\hline \multicolumn{1}{|c|}{ Substrate } & $\begin{array}{c}\text { Concentration } \\
(\mathrm{mM})\end{array}$ & $\begin{array}{c}\text { Specific activity } \\
{\left[\mathrm{nmole} \text { P }_{\mathrm{i}} \text { released }\right.} \\
\left.(\mathrm{mg})^{-1} \text { protein }^{-1}\right]\end{array}$ & $\begin{array}{c}\text { An average } \\
\text { activity } \\
(\%)\end{array}$ \\
\hline $\begin{array}{l}\text { D-fructose-1,6- } \\
\text { bisphosphate }\end{array}$ & 0.2 & $3942.17 \pm 187.76$ & 100.00 \\
\hline D-glucose-6-P & 0.2 & 0.00 & 0.00 \\
\hline D-fructose-6-P & 0.2 & 0.00 & 0.00 \\
\hline D-galactose-6-P & 0.2 & 0.00 & 0.00 \\
\hline D-Mannose-6-P & 0.2 & 0.00 & 0.00 \\
\hline
\end{tabular}

Sprouting of sporocarps is dependent largely on the heterosachharide pectin, which besides providing mechanical strength and protection also helps the cells to cope up with the stress. Unequivocally, it is known that adequate glucose concentration is the central parameter of all living organisms for optimization of biological balance and for successful fulfillment of all metabolic events either directly or indirectly (Eckstein et al., 2012). It is also well established that under certain physiological conditions, the required concentration of glucose can be provided by non-photosynthetic pathway like gluconeogenesis. Since very little is known regarding the principal pathways of carbohydrate metabolism in fern sporocarps, the possibility of a gluconeogenic pathway in senescent fern sporocarps cannot be ruled out. Enzymatic studies on aquatic ferns have been conducted partially and discretely by Soltis and Soltis (1986), but their findings did not throw any light regarding the source of carbohydrates or sugars that are essentially required for growth and development of fern soprocarps, particularly at that time when the concerned vegetative mother plant becomes senescent and its photosynthetic efficiency and solute translocation remain on a low-level.

The present work accords with the pilot indication for the unique presence of the gluconeogenic fructose-1, 6-bisphosphatase for the first time in sporocarps of three heterosporous water ferns followed by its partial purification from mature sporocarps of Marsilea minuta. The results obtained in the present investigation reinvents the primordial nature of this protein in aquatic fern system. The persistence of this enzyme in vascular cryptogams and its alliance with the process of gluconeogenesis can clearly be proved through its catabolic suppression by glucose and simultaneously its lack of response under any light activation which is strongly evident in photosynthetic form of this enzyme (Fig. 1, A-F).

Previous reports dealing with the characterization of cytosolic FBPase have elucidated that the enzyme 
has a high affinity for its substrate (FBP), neutral $\mathrm{pH}$ optima, is inhibited by AMP and glucose and is also strongly stimulated by $\mathrm{Mg}^{+2}$ (Kobr, Beevers, 1971; Dey et al., 2014). The rudimentary characters of this enzyme illustrated in the present study are also comparable to other genera (Kobr, Beevers, 1971; Botha, Turpin, 1990; Jardon et al., 2008; Say, Fuchs, 2010; Yu, 1989). The preeminent activity of this FBPase in mature sporocarps in comparison with the young developing sporocarps (Table 1) nurtures a fundamental question regarding its physiological connotation, which is yet to be conclusively resolved. Is it a 'safe-guard' metabolic strategy for maintenance of the reserve carbohydrate pool during the stressful sprouting phase? In order to provide a satisfactory answer, further work may be carried out with the aid of radio isotope study, gene expression and proteomic analysis.

\section{Conclusion}

The present communication thus reports substantial activity of gluconeogenic FBPase in senescent spore bearing structures of three common heterosporous aquatic ferns. This ancient cytosolic enzyme (purified partially from Marsilea minuta sporocarps) was recognized as a gluconeogenic enzyme, due to its drastic inactivation in presence of glucose and its insensitivity towards photosynthetic light illumination. The results obtained in the present study also reveal the fact that a gluconeogenic pathway is operative in senescent sporocarps of Marsilea minuta, which may be regarded as a metabolic protective strategy adopted by the aquatic ferns for maintenance of the reserve carbohydrate pool during the stressful sprouting phase.

\section{Declaration of Competing Interest}

The authors declare that they have no conflict of interest.

\section{Acknowledgements}

The authors are indebted to DBT, Govt. of West Bengal, India, for a partial financial support (Project No.: 118/10/BT (Estt)/1P-4/2013 dated 15.02.2017) to carry out this work. They are also thankful to Prof. Debesh Roy, Principal, Barasat Govt. College for his continuous help and encouragement.

\section{References}

Adhikari J., Majumder A., Bhaduri T.J., DasGupta S., Majumder A.L. 1987. Chloroplast as a locale of L-myoinositol-1-phosphate synthase. Plant Physiology, 85(3): 611-614.

Arokiyaraj S., Bharanidharan R., Agastian P., Shin H. 2018. Chemical composition, antioxidant activity and antibacterial mechanism of action from Marsilea minuta leaf hexane: methanol extract. Chemistry Central Journal, 12(1): 1-11.

Bierhorst D.W. 1971. Morphology of vascular plants. New York: MacMillan, 137 pp.

Biswas T., Adhikari J., Choudhuri R.B., Majumder A.L. 1981. Fructose-1,6-bisphosphatase \& myo-inositol synthase: A phylogenetic search. Indian Journal of Biochemistry and Biophysics, 18(6): 442-444.

Bold H.C., Alexopoulos C.J., Delevoryas T. 1987. Morphology of plants and fungi. $5^{\text {th }}$ ed. Harpercollins College: Harper \& Row, 912 pp.

Bollag D.M., Rozycki M.D., Edelstein S.J. 1996. Protein methods. New York: Wiley-Liss, 415 pp.

Botha F.C., Turpin D.H. 1990. Fructose 1,6-bisphosphatase inthe green algae Selenastrum minutum. I. Evidence for the presence of isoenzymes. Plant Physiology, 93(4): 1460-1465.

Bower F.O. 1928. The ferns, vol. 3. Cambridge: Cambridge University Press, $359 \mathrm{pp}$.

Bradford M.M. 1976. A rapid and sensitive method for the quantitation of microgram quantities of proteins utilizing principle of protein-dye binding. Analytical Biochemistry, 72: $248-254$.

Chen P.S., Toribara T.Y., Warner H. 1956. Microdetermination of phosphorous. Analytical Chemistry, 28(11): 1756-1758.

Dey A., Lahiri A., Basak A., Adhikari J. 2014. Characterization of gluconeogenic fructose-1,6-bisphosphatase in the senescent thalli of an alga Cladophora bengalensis Martens. Indian Journal of Plant Physiology, 19: 8-13.

Eames A.J.1936. Morphology of vascular plants. New York: McGraw-Hill, 433 pp.

Eckstein A., Zięba P., Gabryś H. 2012. Sugar and light effects on the condition of the photosynthetic apparatus of Arabidopsis thaliana cultured in vitro. Journal of Plant Growth Regulation, 31(1): 90-101.

Gifford E.M., Foster A.S. 1987. Morphology and evolution of vascular plants. $3^{\text {rd }}$ ed. New York: W.H. Freeman and Company, pp. 306-313.

Jardon R., Gancedo C., Flores C.L. 2008. The gluconeogenic enzyme fructose-1,6-bisphosphatase is dispensable for growth of the yeast Yarrowia lipolytica in gluconeogenic substrates. Eukaryotic Cell, 7(10): 1742-1749.

Johnson D.M. 1985. New records for longevity of Marsilea sporocarps. American Fern Journal, 75: 30-31.

Kobr M.J., Beevers H. 1971. Gluconeogenesis in the castor bean endosperm. I. Changes in glycolytic intermediates. Plant Physiology, 47(1): 48-52. 
Kramer K.U. 1990. Marsileaceae. In: Kramer K.U., Green P.S. (eds). Pteridophytes and Gymnosperms. The Families and Genera of Vascular Plants, vol. 1. Berlin; Heidelberg: Springer, pp. 180-183.

Nagalingum N.S., Schneider H., Pryer K.M. 2006. Comparative morphology of reproductive structures in heterosporous water ferns and a re-evaluation of the sporocarp. International Journal of Plant Sciences, 167(4): 805-815.

Raubeson L.A., Stein D.B., Conant D.S. 1994. Insights into fern evolution from mapping chloroplast genomes. American Journal of Botany, 81(6): 123.

Rothwell G.W., Stockey R.A. 1994. The role of Hydropteris pinnata gen. et sp. nov. in reconstructing the cladistics of heterosporous ferns. American Journal of Botany, 81(4): 479-492.

Say R.A., Fuchs G. 2010. Fructose 1,6-bisphosphate aldolase/ phosphatase may be an ancestral gluconeogenic enzyme. Nature, 464 (7291): 1077-1081.

Soltis D.E., Soltis P.S. 1986. Active enzymes from megaspores of Marsilea and Regnellidium. American Fern Journal, 76(1): 17-20.
Sood A., Uniyal P.L., Prasanna R., Ahluwalia A.S. 2012. Phytoremediation potential of aquatic macrophyte, Azolla. Ambio, 41(2): 122-137.

Stitt M., Heldt H.W. 1985. Control of photosynthetic sucrose synthesis by fructose-2,6-bisphosphate. Planta, 164(2): 179-188.

Tryon R.M., Tryon A.F. 1982. Ferns and allied plants, with special reference to tropical America. New York: Springer, $857 \mathrm{pp}$.

Yu S. 1989. Partial purification of fructose 1,6-bisphosphatase from the marine macro alga Bryopsis corticulans (Chlorophyceae). Journal of Phycology, 25: 608-612.

Zimmermann G., Kelly G.J., Latzko E. 1978. Purification and properties of spinach leaf cytoplasmic fructose-1,6bisphosphatase. Journal of Biological Chemistry, 253(17): 5952-5956.

Recommended for publication by O.K. Zolotareva 